First publ. in: The impact of climate change on European lakes / ed.: Glen George. (Aquatic ecology series ; 4) - Dordrecht ; Heidelberg [u.a.] : Springer, 2010, pp. 253-274

\title{
The Impact of Variations in the Climate on Seasonal Dynamics of Phytoplankton
}

\author{
Peeter Nõges, Rita Adrian, Orlane Anneville, Lauri Arvola, Thorsten \\ Blenckner, Glen George, Thomas Jankowski, Marko Järvinen, Stephen \\ Maberly, Judit Padisák, Dietmar Straile, Katrin Teubner, and Gesa \\ Weyhenmeyer
}

\subsection{Introduction}

Phytoplankton, an assemblage of suspended, primarily autotrophic single cells and colonies, forms part of the base of the pelagic food chain in lakes. The responses of phytoplankton to anthropogenic pressures frequently provide the most visible indication of a long-term change in water quality. Several attributes related to the growth and composition of phytoplankton, such as their community structure, abundance as well as the frequency and the intensity of blooms, are included as indicators of water quality in the Water Framework Directive. The growth and seasonal succession of phytoplankton is regulated by a variety of external as well as internal factors (Reynolds et al., 1993; Reynolds, 2006). Among the most important external factors are light, temperature, and those associated with the supply of nutrients from point and diffuse sources in the catchment. The internal factors include the residence time of the lakes, the underwater light regime and the mixing characteristics of the water column. The schematic diagram (Fig. 14.1) shows some of the ways in which systematic changes in the climate can modulate these seasonal and inter-annual variations. The effects associated with the projected changes in the rainfall are likely to be most pronounced in small lakes with short residence times (see George et al., 2004 for some examples). In contrast, those connected with the projected changes in irradiance and wind mixing, are likely to be most important in deep, thermally stratified lakes.

In this chapter, we use results acquired from a range of different European lakes to explore the potential effects of climate change on the seasonal development and the composition of phytoplankton. The time-series analysed are amongst the longest available in the region. Some of the lakes studied in CLIME have been sampled at weekly or fortnightly intervals for more than fifty years. These sites also cover a range of lake types from shallow to deep, small to large, and oligotrophic to eutrophic.

\author{
P. Nõges (ख) \\ Estonian University of Life Sciences, Kreutzwaldi Str. 64, 51014, Tartu, Estonia \\ e-mail: peeter.noges@emu.ee
}

Konstanzer Online-Publikations-System (KOPS) 


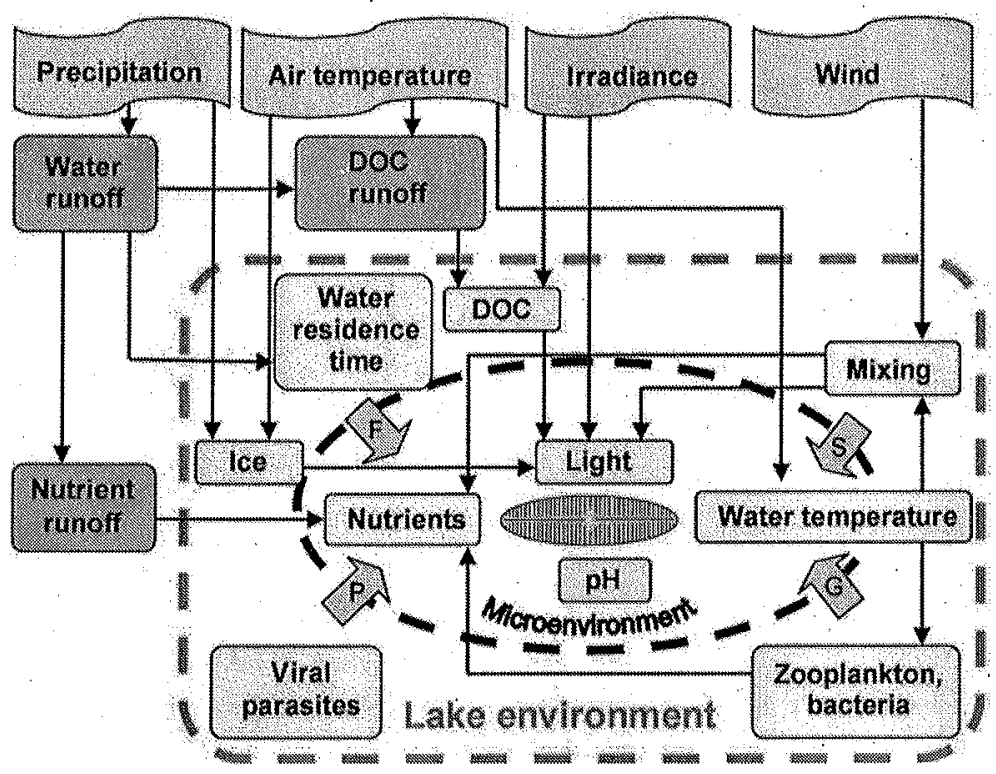

Fig. 14.1 The mechanisms involved in mediating the climatic responses of phytoplankton. The elimination mechanisms are indicated by block arrows: $\mathrm{F}$ - flushing by extensive water exchange; $\mathrm{S}$ - sedimentation in a stagnant water column, $\mathrm{G}$ - grazing by zooplankton, $\mathrm{P}$ - parasitism.

Geographically the lakes represent the Nordic, Atlantic, Central European and Alpine climatic and eco-regions. Besides specific CLIME sites, examples from other lakes are included where appropriate. Here, we concentrate our attention on the changes observed over the last 30 years, a period of particularly rapid change in most of the catchments selected for study. Issues that greatly complicate the analysis of long-term climate change impact on lakes, are the complementary trends of eutrophication and re-oligotrophication. These management-related problems can, however, be minimized by using appropriate de-trending techniques and drawing comparisons with model simulations.

\subsection{The Impact of Changes in the Weather on the Seasonal Dynamics of Phytoplankton}

\subsubsection{Winter}

In Northern Europe and the Alpine regions of Central Europe, the lakes are usually covered with ice throughout the winter (Fig. 14.2). Cold monomictic lakes in the sub-arctic and high alpine areas experience only a short ice-free period in summer, while lakes in maritime areas in Western Europe seldom freeze during the winter. Most recent climate change scenarios suggest that there will be a marked increase 
Fig. 14.2 The distribution of ice-covered lakes in Europe. Areas with mean air temperature in January $<0^{\circ} \mathrm{C}$ (black) are more likely to have lakes with sustained winter ice-cover. Deep lakes that store more heat, may represent exceptions.

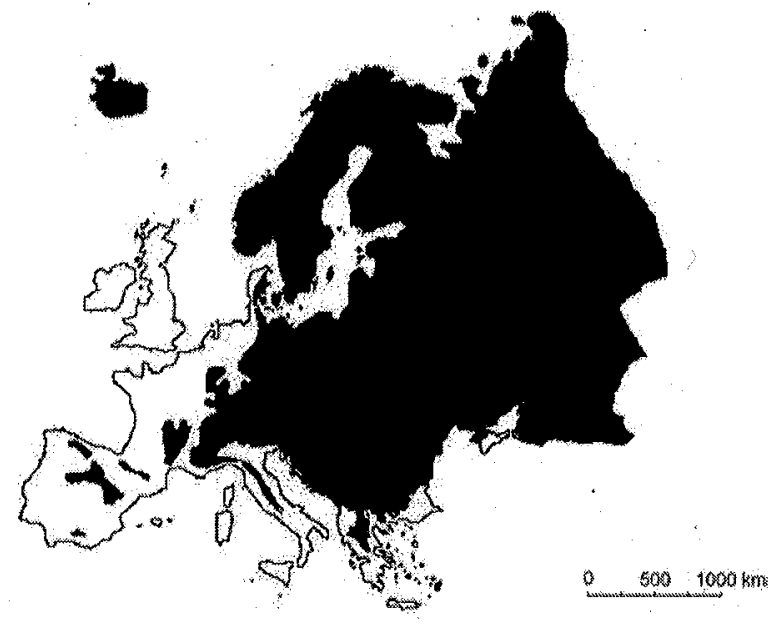

in European winter temperatures accompanied by a pronounced extension of the ice-free period (see Chapters 2, 4 and 6, this volume). Large ecological changes have been observed in lakes which have totally lost their winter ice-cover and lakes which were previously covered with ice but have now become temporarily ice-free (Psenner, 2003). Ohlendorf et al. (2000) concluded from their observations on a remote high alpine lake that the mere occurrence of an ice-free period, creating a short productivity pulse, was more important than its duration for preserving a climatic signal in the sedimentary record.

During the ice-cover period, especially when there is thick snow on the ice, photosynthesis becomes severely light-limited and most species of phytoplankton sink in the water column despite some convective mixing. Exceptionally, some motile algae like dinophytes (Arvola and Kankaala, 1989; Weyhenmeyer et al., 1999), cryptophytes (Arvola and Kankaala, 1989; Phillips and Fawley, 2002), chrysophytes (Watson et al., 2001) or flagellated chlorophytes (Arvola and Kankaala, 1989) can concentrate near the surface and give rise to late winter blooms particularly if the ice is clear of snow (Jones, 1991). In Lake Erken, high chlorophyll $a$ concentrations were recorded both when the spring peak occurred below the ice and after the ice break-up (Fig. 14.3A). The relative abundance of diatoms was, however, low when the spring peak occurred below the ice (Fig. 14.3B), primarily due to the importance of wind mixing for the large diatoms. Winter diatom blooms, like those dominated by the very small Stephanocostis chantaicus in Lake Stechlin, Germany (Scheffler and Padisák, 2000) or by Aulacoseira baicalensis in Lake Baikal (Kozhov, 1963; Kozhova and Ismest'eva, 1998), are most probably supported by convectional currents (Kelley, 1997; Granin et al., 1999). In winter, any nutrients discharged by rivers or released by decomposition in the water column or the bottom sediments accumulate under the ice and allow a more rapid growth of phytoplankton after ice 


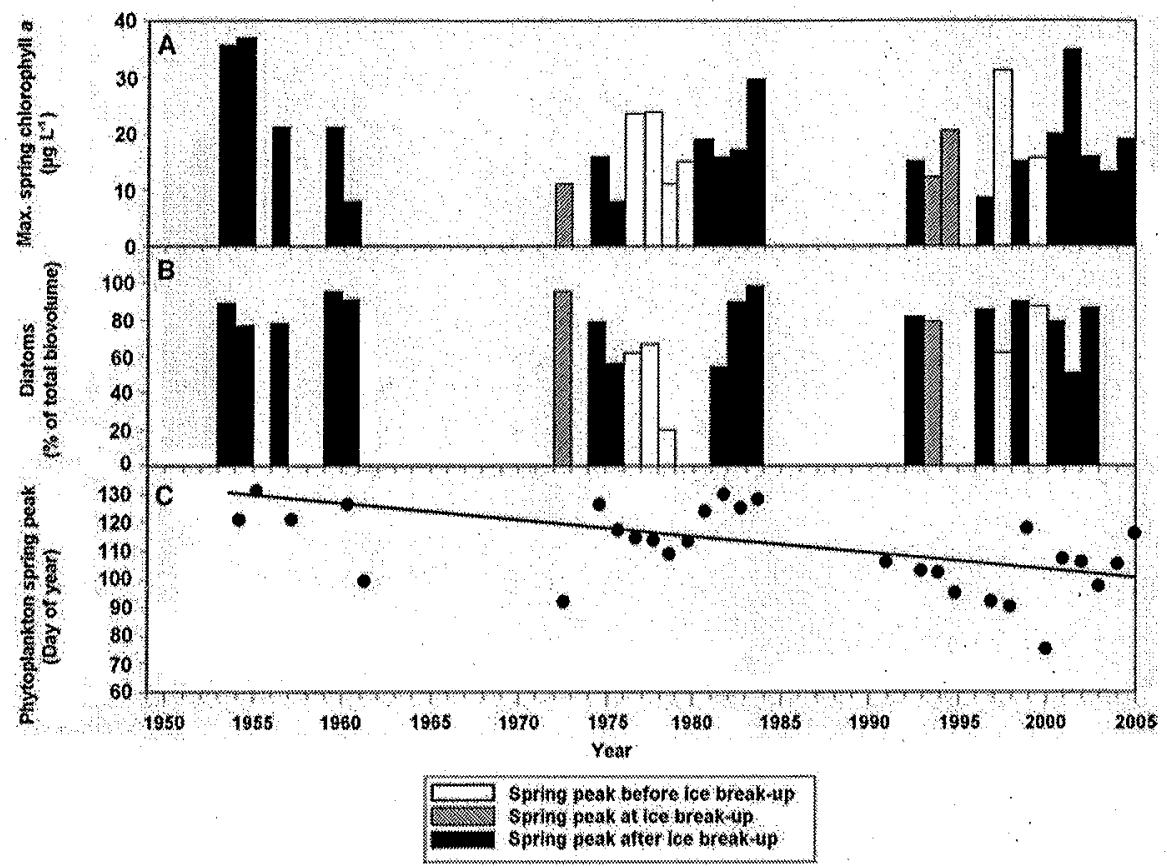

Fig. 14.3 Development of phytoplankton spring peak in Lake Erken based on at least weekly measurements in 1954-2005. (A) Maximum measured Chl a concentrations, (B) The percentage of diatoms in the total phytoplankton biovolume during spring peak. (C) Timing of the phytoplankton spring peak and its trend (Weyhenmeyer et al., 1999 updated with latest data).

break-up when light conditions improve. In deep lakes there may, however, be some delay due to complete vernal turnover as described in a later section.

In Western Europe, where the lakes are either ice-free or only freeze for a few days in the year (George, 2007), the most important winter effects are those associated with the year-to-year variations in the rainfall. In the English Lake District, George et al. (2004) showed that heavy winter rains tend to transport more dissolved reactive phosphate into the lakes but may also reduce the standing crop of phytoplankton by their flushing effect. The ecological response of the lakes to these flushing events is critically dependent on their residence time. In Blelham Tarn, a lake with an average residence time of 42 days, wet winters severely depleted the standing crop of phytoplankton (Fig. 14.4a). In contrast, in the North Basin of Windermere (Fig. 14.4b), a lake with an average residence time of 185 days, wet winters had no significant effect on the average biomass of phytoplankton. In some lakes, these flushing effects can even influence the composition of the phytoplankton much later in the year by reducing the size of the inocula that produce the early summer maxima.

In the deep perialpine lakes of Central Europe, the internal recycling of nutrients and the subsequent development of the phytoplankton are strongly influenced by the 
(A)

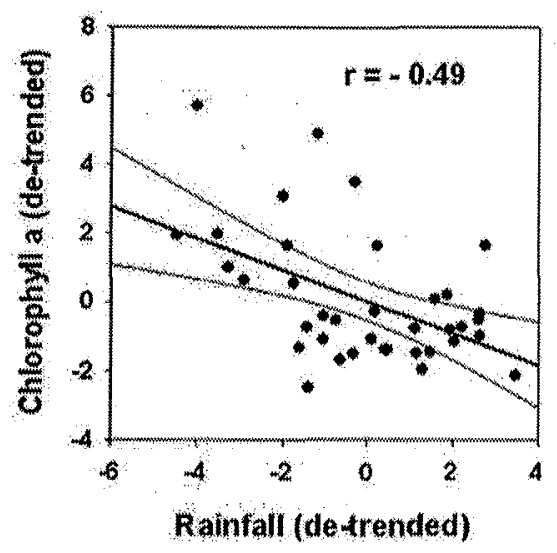

(B)

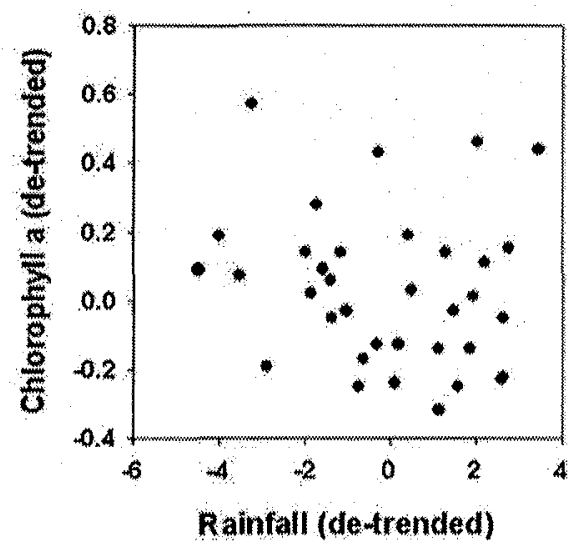

Fig. 14.4 Influence of winter rainfall on the de-trended winter concentration of phytoplankton chlorophyll in Blelham Tarn (A) and the north basin of Windermere (B). (Data jointly managed by the FBA and CEH).

duration and intensity of vertical mixing in winter and early spring (Salmaso, 2002, 2005; Straile et al., 2003). The occurrence of several consecutive mild winters leads to incomplete mixing in such lakes, which further results in a gradual increase in deep-water temperature and a simultaneous decrease in deep-water oxygen concentrations. These gradual changes can be terminated by the occurrence of an unusually cold winter - or even an average winter, if the deep-water temperature has risen to a sufficiently high level. This then results in deep penetrative mixing, an abrupt fall in deep-water temperature and an abrupt rise in deep-water oxygen concentrations (Livingstone, 1997). Late winter and early spring may therefore be considered the most critical period in the annual cycle of deep lakes (Salmaso, 2005). During cold winters with a complete overturn in Lake Garda, total phosphorus concentrations in the euphotic layer exceeded those of milder winters by a factor of three and favoured the development of Mougeotia sp. and Oscillatoriales (Salmaso, 2002).

\subsubsection{Spring}

In lakes covered with ice, the disappearance of snow from the ice and the timing of break-up are crucial events for the development of the spring phytoplankton (Tulonen et al., 1994; Weyhenmeyer et al., 1999; Gerten and Adrian, 2000; Straile and Adrian, 2000). An earlier spring bloom in years following earlier ice breakup has been observed in lakes Müggelsee (Adrian et al., 1999) and Erken (Weyhenmeyer et al., 1999).

In Lake Erken, the spring peak of phytoplankton has advanced by about one month over the last 50 years (see Fig. 14.3C). Here, the timing of the ice-break and 
Fig. 14.5 Timing of the phytoplankton spring peak vs. the timing of ice breakup in Lake Erken for the period 1954-2005 (Weyhenmeyer et al., 1999 updated with more recent data)

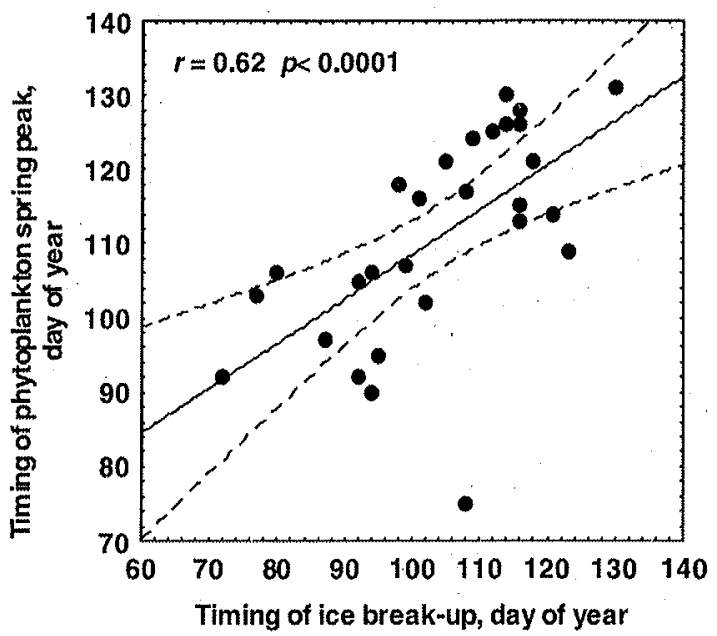

the timing, composition and magnitude of the spring bloom (Fig. 14.5) depend on the weather experienced in March. In contrast, the duration of the spring bloom and the length of the post-bloom period are primarily controlled by nutrient availability (Blenckner, 2001). Since the size of the available nutrient pool differs from lake to lake, the decline of spring phytoplankton is not directly linked to the timing of ice break. Early ice-break combined with an early spring bloom may, however, result in an accelerated rate of nutrient depletion and an earlier decline in the early spring phytoplankton (Weyhenmeyer, 2001; Järvinen et al., 2006).

Owing to their smaller volumes, reduced heat storage, and shorter residence times, shallow lakes respond in a more direct way to inter-annual variations in the weather. In small, non-stratified, lakes, the climatic 'signal' captured during the spring turnover persists for only a short period of time (Gerten and Adrian, 2000). In contrast, some large but shallow lakes, like Lake Võrtsjärv, have an extended 'climate memory' and here the meteorological conditions experienced in winter and early spring determine to a large extent both the water level and the dynamics of the phytoplankton throughout the ice-free period (Nõges, 2004; Nõges et al., 2003).

In lakes without winter ice-cover, the timing of the spring bloom is not so strictly determined by one climatic variable. The transition period from winter to summer is smoother and the lakes 'integrate' the different elements of the climate signal in functionally different ways. In the lakes of the English Lake District, there is mounting evidence that the spring blooms are appearing earlier in the year. In the four Windermere lakes (Fig. 14.6) this trend is statistically significant only in two basins: the north basin of Windermere and Esthwaite Water. The observed rates of advance (4.2 and 5.8 days per decade) are at the upper end of that reported for the phenology of plants in terrestrial systems (Walther et al., 2002). The different responses observed in the individual lakes suggest that the timing of this key event is influenced by factors other than the water temperature. Initial analyses suggest 
(A)

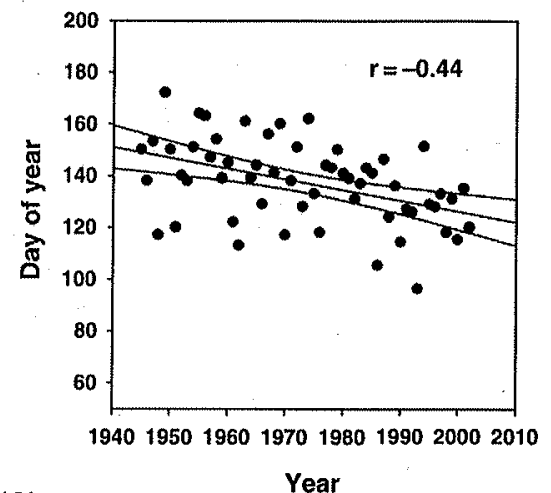

(C)

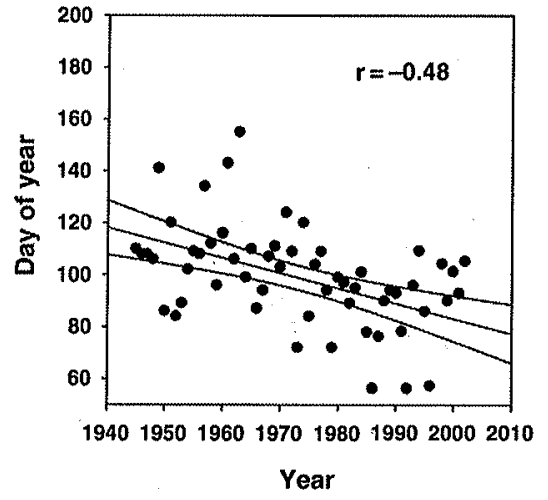

(B)

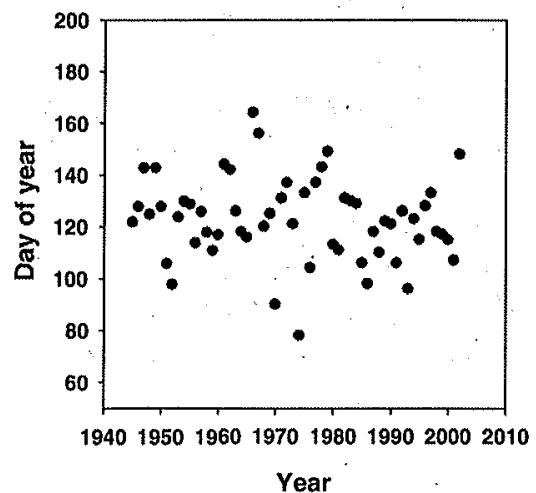

(D)

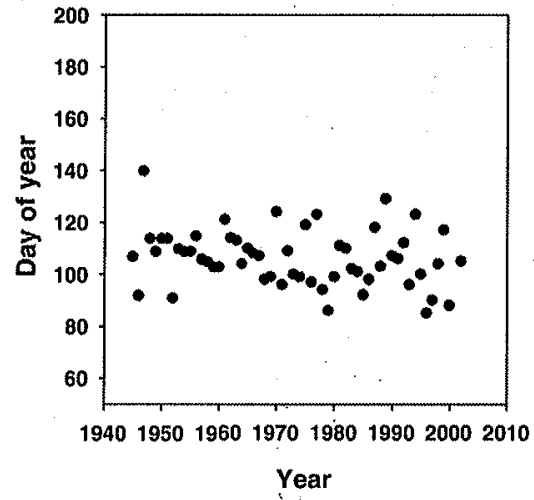

Fig. 14.6 The timing of the spring maximum of Asterionella formosa in four English lakes between 1945 and 2002. (A) North Basin of Windermere. (B) South Basin of Windermere. (C) Esthwaite Water. (D) Blelham Tarn. (Data jointly owned by the FBA and CEH - S.C. Maberly, unpublished).

that the timing of the bloom is controlled by a combination of factors that include warmer spring temperature, the increased availability of phosphate and the interannual variations in the rainfall (S.C. Maberly, unpublished). The apparent absence of a similar advance in Blelham Tarn may be attributed to the recently recorded increase in the winter rainfall (George et al., 2007) and the effect of the increased flushing rate on the development of the spring bloom.

In the deep lakes of Central Europe, spring mixing has a dual effect on phytoplankton development. Besides the replenishing effect of deep mixing on the nutrients in the epilimnion, the downward mixing of phytoplankton into aphotic layers seriously inhibits its growth (Huisman and Weissing, 1994; Steel and Duncan, 1999; Reynolds, 2006). In Lake Constance, a large and deep perialpine lake that seldom freezes, the onset of the spring phytoplankton bloom is largely controlled by turbulent diffusion, that is, by the transition from strong mixing in winter and early 
spring to weak mixing in summer (Peeters et al., 2007). Consequently, the onset of the bloom is closely correlated with the onset of thermal stratification, which in turn is determined by a complex interplay between temperature and wind (Peeters et al.; 2007). Only when the depth of mixing is reduced to ca $40 \mathrm{~m}$, does the improvement in the underwater light climate stimulate a marked increase in net growth rate of the phytoplankton which heralds the start of a bloom, (Peeters et al., 2007). A strong control of spring phytoplankton growth by vertical mixing seems to be rather a rule than an exception. As reported by Straile and Adrian (2000), phytoplankton growth in Lake Constance was inhibited by wind-induced reductions in the underwater light throughout the 16-year period (1979-1994) covered by their study.

\subsubsection{Summer and Autumn}

In many of the CLIME lakes, there has been a significant change in the phytoplankton growth patterns observed in early summer. At that time of year, many lakes experience a clear water phase, i.e. a period when the biomass of the phytoplankton declines sharply. In most cases, this decline has been related to zooplankton (Daphnia) grazing. Detailed accounts of this phenomenon have been given for lakes in Northern Europe (Gerten and Adrian, 2000; Weyhenmeyer, 2001; Adrian et al., 2006), Western Europe (Talling, 2003) and Central Europe (Straile, 2000; Straile and Adrian, 2000; Anneville et al,, 2002a, b). In warmer years, a biomass of Daphnia, large enough to limit the growth of phytoplankton, is reached earlier in the year and results in an earlier and longer lasting clear-water phase. These effects appear to be lake specific: in shallow Müggelsee, spring water temperatures and Daphnia abundance both increased more rapidly than in large, deep Lake Constance. Consequently, the clear water phase started about three weeks earlier in Müggelsee than in Lake Constance (Straile and Adrian, 2000). The climatic responses observed in autotrophic species may not, however, be mirrored by heterotrophic species (Blenckner, 2005) since the processes responsible for the decay and recycling of the autotrophs are often lake specific. For example, in Lake Stechlin, spring diatoms simply sink as soon as the lake starts to stratify and the clear water phase is not connected with any grazing effects (Padisák, et al., 2003b). In some cases, the processes responsible for the breakdown and decomposition of the cells are markedly non-linear whilst in others they have critical thresholds. Cell death through parasitism may also account for significant proportion of phytoplankton loss in many lakes (Jassby and Goldman, 1974).

At some sites, causal links have been established between the meteorological conditions experienced in winter or early spring and events in the plankton the following summer. In large and shallow Lake Vôrtsjärv in Estonia $\left(270 \mathrm{~km}^{2}\right.$, mean depth $2.8 \mathrm{~m}$ ), large year-to-year differences in the water level have a very pronounced effect on the development of the phytoplankton (Nõges, 2004; Nõges et al., 2003). The magnitude of the spring floods, determined largely by the winter air temperature and precipitation, explains most of the variability in annual mean water 
levels $\left(R^{2}=0.85, p<0.0001\right)$. When the level is low, the water is enriched with phosphorus by sediment resuspension and there is an associated reduction in the nitrate concentration due to denitrification. Since 1964, the phytoplankton biomass has been significantly lower in years of high water level, a pattern that was not related to any change in external loading of nutrients. These fluctuating water levels have also had an effect on the qualitative composition of the phytoplankton. During high-water periods, Limnothrix redekei and $L$. planktonica have typically accounted for more than $90 \%$ of the total wet weight of phytoplankton, which has remained under $30 \mathrm{~g} \mathrm{~m}^{-3}$, even when the external nutrient loading was high. Limnothrix species can, by virtue of their shape and photoadaptive properties, maintain much higher growth rates than most other species when light levels are low (Gibson, 1987; Ruicker et al., 1997). During low-water periods, the wet weight of phytoplankton has often exceeded $30 \mathrm{~g} \mathrm{~m}^{-3}$ and even reached a $100 \mathrm{~g} \mathrm{~m}^{-3}$ in the 1970s. During the 1990s and 2000s, low-water periods have also been characterized by an increase in the nitrogen-fixing species, Aphanizomenon skujae. Compared to Limnothrix, Aphanizomenon species need higher light levels (Foy et al., 1976) and are favoured by increased illumination in shallow water. Nitrogen fixation, recurrently measured in Lake Võrtsjärv in summers with low water levels, has likely been triggered by increased nitrogen losses due to denitrification (Tõnno and Nõges, 2003).

In Lake Geneva (Anneville et al., 2002a, b), the increase in the spring phytoplankton in warmer years, together with the decrease in phosphorus loading, have led to an earlier and more pronounced depletion of phosphorus in the productive layer. By mid-summer, the P-depleted layer often extends below the depth where the availability of light is the limiting factor $(15-25 \mathrm{~m})$. In these conditions, the midsummer community is dominated by a complex of species, which are well adapted to low light levels and shorter days (e.g., Mougeotia gracillima and Diatoma tenuis). Species of this shape and size have an obvious competitive advantage when nutrients are low, due to their large surface to volume ratio and their size which renders them less vulnerable to grazing by zooplankton. Thus, these large species can survive and eventually achieve a greater biomass despite their relatively slow growth.

The most important weather-related effect observed in many of the CLIME lakes was the change in the timing of thermal stratification and the consequent extension of the summer growth period. These effects were particularly pronounced in Northern Europe where the extension of the growing season in several mesotrophic lakes mimicked the effects commonly associated with eutrophication. For example, in Lake Erken, Sweden, the oxygen concentrations recorded in the hypolimnion in late summer are critically dependent on the length of the stratification period and the transfer of heat into the deep water (Pettersson et al., 2003). A comparison of the oxygen concentrations measured in the hyplimnion in a series of relatively cold (1975-1979) and relatively warm (1994-2001) summers showed that the concentration in August decreased from an average of $4.2 \mathrm{mg} \mathrm{l}^{-1}$ to an average of $2.5 \mathrm{mg} \mathrm{l}^{-1}$ (data for $15 \mathrm{~m}$ depth differed significantly $\mathrm{p}<0.05$ ). This reduction was, in turn, responsible for a sustained increase in the concentrations of phosphate and ammonium in the hypolimnion and an intensification of internal nutrient cycling 
(Chapter 15 this volume). A very similar deterioration in the quality of the water was observed in Heiligensee, a hypeutrophic lake in North Germany. Here, time series analyses for the period 1975-1992 showed an abrupt change in the structure of the phytoplankton community, centred on the late 1980s and early 1990s (Adrian et al., 1995). In Heiligensee, the earlier onset and longer duration of thermal stratification influenced the system in two different ways: (i) There was a rapid collapse of the spring diatoms as soluble reactive silicon was depleted and more cells were lost through sedimentation. (ii) There was a marked increase in the concentrations of phosphorus recorded in the hypolimnion at the end of summer that explained $69 \%$ of the variation in maximum algal standing stock recorded in the autumn.

In Western Europe, the growth patterns recorded during the summer have also changed in a systematic way. In the English Lake District, samples for chlorophyll analysis have been collected from four lakes at weekly or fortnightly intervals since 1964 (Talling, 1993). In these lakes, the growth cycle follows a 'diacmic' pattern with well defined maxima in the spring and summer. Despite this intensive sampling, the duration of the summer growth period can still only be estimated by fitting a Gaussian model to the raw observations. The model used has been described by George and Hurley (2004) and is based on fitting two Gaussian curves to the logarithm of the chlorophyll measurements:

$$
\ln (C(t))=a+b_{1} G\left(t ; \mu_{1}, \sigma_{l}\right)+b_{2} G\left(t ; \mu_{2}, \sigma_{2}\right)
$$

where $t$ is the proportion of time that has elapsed from a defined starting date (31 December) and $\sigma_{2}$ is a measure of the duration of the summer growth period. Figure 14.7 a show the result of fitting this model to some example results for 1988. The samples were collected from the North Basin of Windermere, a relatively unproduetive lake with a maximum depth of $60 \mathrm{~m}$. Here, the fitted model explained a high proportion of the observed variation and provided a reliable measure of the 'summer growth' parameter $(\sigma 2)$. Figure $14.7 \mathrm{~b}$ shows the long-term change in the value of this parameter. In the 1970 s and 1980 s this parameter remained relatively constant, büt it increased sharply in the 1990s. The Cumulative Sum (CuSum) plot in Fig. 14:7c shows that the pivotal year was 1993. An analysis of the internal and external factors responsible for this change showed that the key factor was the increased physical stability of the lake. Figure $14.7 \mathrm{~d}$ is a CuSum plot of the change in the summer stability, as measured by the index described by Schmidt (1928). Statistical tests showed that the value of the $\sigma 2$ parameter only exceeded the "control limits' in 1993, i.e. the year when there had been a marked increase in the summer stability of the lake. The phytoplankton species that dominate the open water in late summer are particularly responsive to the extension of the growing season. Most of these species grow quite slowly, so an additional cell division in late summer can have a major effect on their maximum biomass.

The other factor influencing the development of some slow growing species is the short-term variation in the intensity of wind-induced mixing. The lakes situated on the western seaboard of Europe are particularly sensitive to these physical effects (George, 2000a). In the more productive lakes in the English Lake District, 
(A)
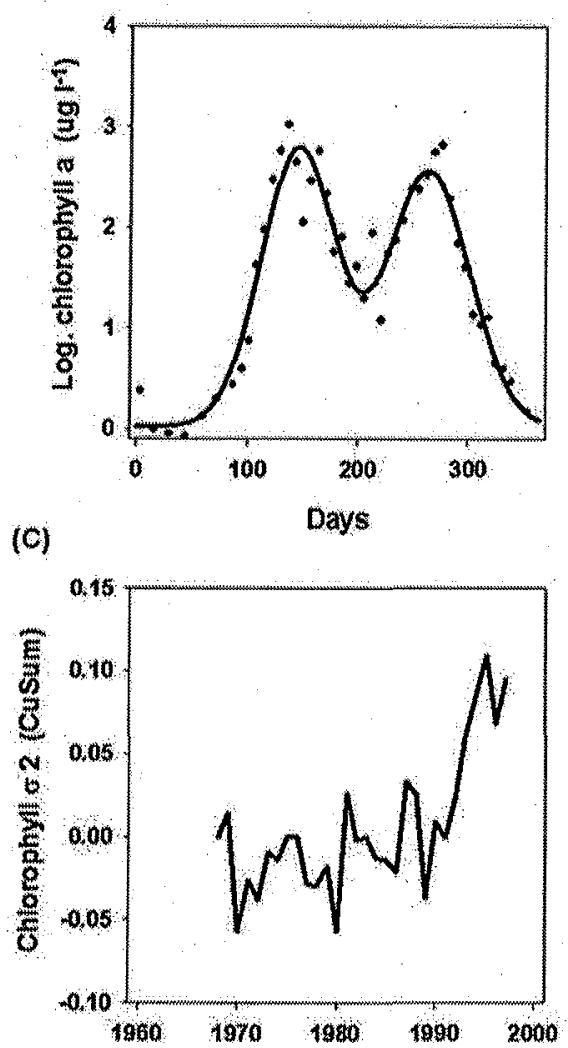

(B)

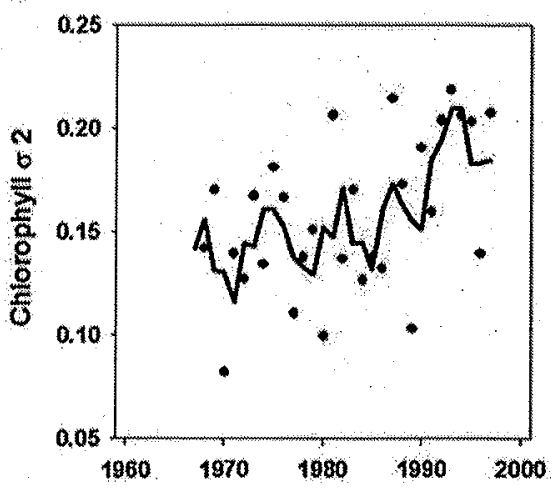

(D)

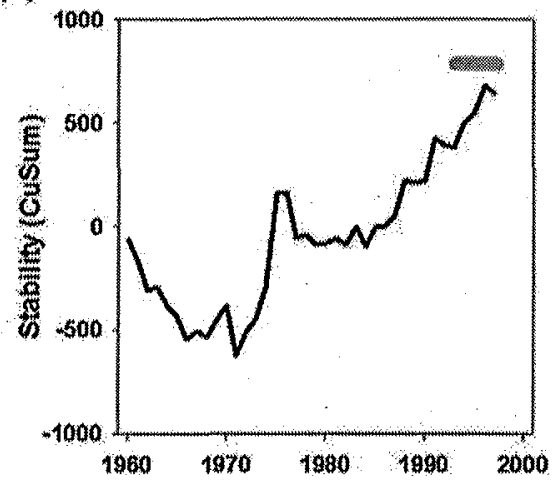

Fig. 14.7 Using a Gaussian model to quantify the change in the duration of the summer growth period in the North Basin of Windermere. A - an example fit for 1988; B - the long-term change in the $\sigma 2$ parameter, an empirical measure of the summer growth period; $\mathrm{C}-$ The Cumulative Sum (CuSum) plot for the $\sigma 2$ parameter; D - The CuSum plot of the long-term change in the summer stability of the water column (measured by the index described by Schmidt (1928)). (Data jointly managed by the FBA and $\mathrm{CEH}$ ).

the seasonal succession of phytoplankton follows a remarkably predictable pattern (Reynolds, 2006). The first species to dominate are mostly diatoms which are then replaced by motile flagellates. These small forms have high rates of growth but can only survive if the water column is periodically mixed by the wind. When the water is warm and there is relatively little wind, slow growing forms like the bloom forming species of cyanobacteria become dominant. Figure 14.8 shows the effect that year-to-year changes in the weather had on the growth of the blue-green alga Aphanizomenon in Esthwaite Water between 1956 and 1972. Once the time-series had been de-trended to remove the effects associated with enrichment, there was a striking correlation $(r=0.82, \mathrm{p}<0.001)$ between the summer abundance of the Aphanizomenon and the stability of the lake. The factors influencing the growth of 
Fig. 14.8 The relationship between the abundance of Aphanizomenon in Esthwaite Water and the stability of the water column in summer. The Aphanizomenon time-series was de-trended to minimise the effects of progressive enrichment. The stability was calculated using the procedure described by Schmidt (1928)

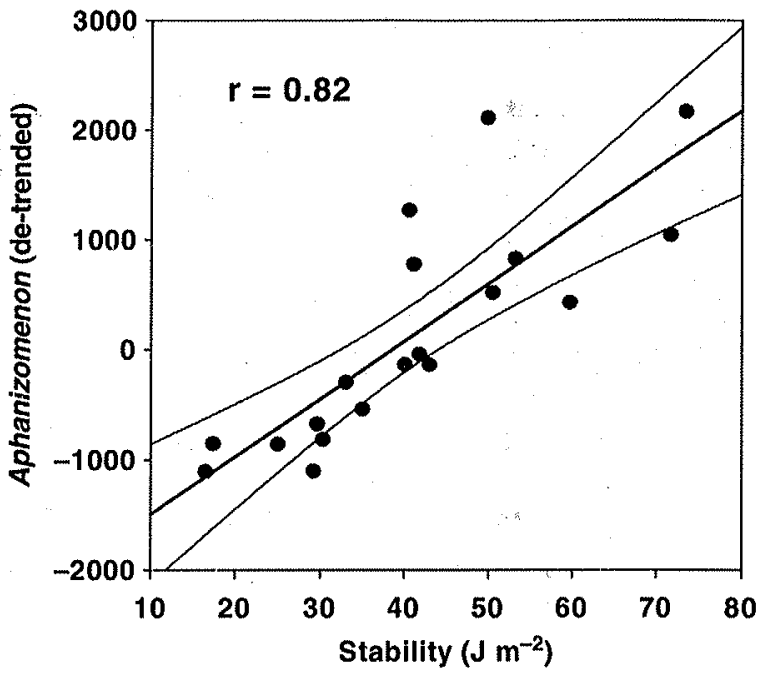

Aphanizomenon in Esthwaite Water have been discussed in more detail by George et al. (1990) and George (2000b). The pattern described is quasi-cyclical and appears to be governed by the position of the Gulf Stream in the eastern Atlantic.

The results of a recent mixing experiment in Lake Nieuwe Meer, a hypertrophic lake in the Netherlands, demonstrates that quite short periods of reduced mixing can have a major effect on the growth of bloom-forming cyanobacteria (Jöhnk et al., 2008). This experiment was conducted during the hot summer of 2003 and showed that the summer heatwave was the main factor responsible for a dense Microcystis bloom. Simulations with a coupled hydrodynamic-phytoplankton competition model showed that high temperatures favoured cyanobacteria both directly, through increased growth rates, and indirectly, by reduced turbulent mixing.. The European summer heatwave of 2003 is considered by many to be a prototype of future summers in the region. Results of this kind imply that, whilst high air temperature per se has an effect on the growth of these species, it is the combination of high temperatures and reduced wind-speed that provides the conditions necessary for the appearance of dense surface blooms.

The growth and development of the autumn phytoplankton is also critically dependent on the mixing characteristics of the lakes. In stratified lakes, the high nutrient concentrations that accumulate in deep water during extended stagnation periods (Adrian et al., 1995) can promote strong water blooms when the overturn starts (Pettersson et al., 2003; Kangro et al., 2005). In polymictic lakes, such as Peipsi and Võrtsjärv, phytoplankton biomass usually increases during the autumn and only declines after the lakes start to freeze (Nõges et al., 2004). When the ice-cover is late, the biomass peak appears later and, since the cells sink slowly in cold water, higher than average biomasses may be recorded for as long as two months after the lakes have frozen. Very deep lakes may have even longer lasting 
'memories' of antecedent conditions and extreme climatic events (Chapter 17 this volume). There is even evidence to suggests that the meteorological conditions experienced during the winter can affects the phytoplankton in the following summer and autumn but the mechanisms are complex and not yet clear (Straile et al., 2003).

\subsection{The Impact of Climate Change on the Structure of the Phytoplankton Community}

\subsubsection{Phytoplankton Species Favoured by Climate Change}

Climate can be considered the major factor determining the distribution of species at a continental scale (Pearson and Dawson, 2003). Small variations in climate can have dramatic effects on biota, especially in extreme habitats, where many species live at the limit of their environmental tolerances. Distribution, composition and species diversity of diatoms in Sub-arctic Lapland are strongly regulated by temperature and other climate-related factors (Weckström and Korhola, 2001; Sorvari et al., 2002). Global warming is projected to cause a northward extension of those species that are better adapted to higher temperatures. As an example, the bloom-forming cyanobacterium Cylindrospermopsis raciborskii is causing increasing concern because of its potential toxicity and invasive behavior at middle latitudes (Padisák, 1997; Briand et al., 2004; Paerl and Huisman, 2008). C. raciborskii, originally classified as a tropical to subtropical species with a higher temperature optimum than most cyanobacteria (Gorzo, 1987), has now been reported in several Central European countries, such as Hungary (Tóth and Padisák, 1986), Austria (Dokulil and Mayer, 1996), France (Couté et al. 1997), Germany (Krienitz and Hegewald, 1996; Stüken et al., 2006) and Poland (Stefaniak and Kokocynski, 2005). In Lake Balaton C. raciborskii blooms now appear in years when summer temperatures are significantly higher than average and there is an active P-pool in the sediments (Padisák, 1998). In the consecutive dry years 2000-2003, the temperature requirements of the species were fulfilled but the sedimentary. P-pool must have been insufficient since no increased growth was actually observed (Padisák et al., 2006).

The increased incidence of metalimnetic or upper hypolimnetic maxima of the cyanobacterium Planktothrix rubescens (considered conspecific with $P$. agardhii by Humbert and Le Berre, 2001) is another phenomenon reported from many stratified lakes (Dokulil and Teubner, 2000; Davis et al., 2003; Teubner et al., 2003, 2006; Padisák et al., 2003a; Anneville et al., 2004; Jacquet et al., 2005; Salmaso, 2005). This species is particularly efficient at harvesting light due to its high phycobiliprotein content (Bright and Walsby, 2000; Greisberger and Teubner, 2007) and ability to optimize its position in the water column (Reynolds et al., 1987). Walsby and his coauthors (Walsby, 2005; Walsby et al., 2006) used a modelling approach to demonstrate that the ability of the Planktothrix rubescens to stratify. in Lake Zürich was related to the size and shape of its filaments, which respond 
to the irradiance by changing their density. This model was also used to explain the Burgundy-blood phenomenon sometimes observed in Lake Zürich in November and December when, after deeper mixing and lower insolation, Planktothrix filaments become buoyant and float to the surface in subsequent calm periods.

Since the 1950s, the eutrophication of many deep, alpine lakes has led to the progressive suppression of Planktothrix, as the light reaching the metalimnion became insufficient (Sas, 1989). The recent success of $P$. rubescens in a number of lakes is most probably caused by a synergetic effect of increased transparency due to the reduction in the phosphorus loads, the deepening of the P-depleted zone and increased water column stability (Anneville et al., 2005; Jacquet et al., 2005; Teubner et al., 2003, 2006). The physiological shift from autotrophic to photoheterotrophic metabolism seems to be crucial for the success of the $P$. rubescens layers that develop below the compensation point. There is also experimental evidence to suggest that acclimatisation to dim-light stimulates the uptake of organic compounds by $P$. rubescens (Zotina et al., 2003).

The depth of winter mixing affects the development of $P$. rubescens in a nonlinear way. Bürgi and Stadelmann (2002) suggested that deeper mixing in Lake Sempach (maximum depth $87 \mathrm{~m}$ ) enhanced the competitiveness of the species by extending the low irradiance zone (see also Bright and Walsby, 2000; Greisberger and Teubner, 2007). However, if the mixing depth exceeds the mean critical pressure depth around $90 \mathrm{~m}$, the gas vesicles in this species collapse (Walsby et al., 1998; Bossard et al., 2001). That observation supports the suggestion made by Anneville et al. (2004) that reduced winter mixing (to 60-100 m) in Lower Zürich lake (maximum depth $136 \mathrm{~m}$ ) in the 1990s may have contributed to the increased abundance of $P$. rubescens during winter. These examples suggest that phytoplankton composition is more sensitive to climate change than is overall phytoplankton biomass. As a result, year-to-year variation in weather may cause synchronous changes in phytoplankton composition over a wide geographical area but smaller effects on biomass.

In some of lakes studied in Central and Northern Europe, recent reductions in their nutrient loads and their subsequent re-oligotrophication further complicates the analysis of change. Jankowski et al. (personal communication) analysed the simultaneous effects of re-oligotrophication and climate variability on phytoplankton diversity using data from CLIME lakes in Central and Northern Europe. They found that lake restoration, i.e. a reduction in the phosphorous loads, has resulted in an increase in phytoplankton diversity. Over the last 25 years, the number of genera reported from these lakes has increased by $20-70 \%$. This trend appears to be universal and was not related to the trophic status of the lakes.

\subsection{Discussion}

Our study on the response of phytoplankton to climatic change across lakes in Europe has shown that systematic changes in the weather have already had a significant effect on the seasonal dynamics of phytoplankton at a number of CLIME sites. 
Many of these changes can be directly related to observed large-scale changes in the climate and regional variations in the circulation of the atmosphere. In winter, the most important effects were those associated with the inter-annual variations in the North Atlantic Oscillation (Chapter 17, this volume), i.e. the duration of ice-cover, rainfall, and wind-induced mixing. In summer, these effects were less pronounced but the dynamics of the thermally stratified lakes was then influenced by the yearto-year variations in the number of warm days with very little wind (Chapter 16 this volume) that had a strong effect on bloom forming cyanobacteria.

In the late 1980 s, the atmospheric pressure gradient quantified by the NAO winter index changed in a systematic way with the index remaining in its positive (mild winter) phase for several years in succession. This shift was accompanied by a major change in the lake temperature regimes observed over most of Europe (Chapter 6 this volume). This effect was most pronounced in 1988 and was manifested as an upward jump separating the earlier 'cold' period from the following 'warm' period (Adrian et al., 1995; Weyhenmeyer, 2001; Weyhenmeyer et al., 2002; Anneville et al., 2005). In some cases, the effects of these mild winters could be detected much later in the year, e.g. when the earlier ice break-up and warming led to an earlier onset of stratification and the growth of summer phytoplankton. In the large lakes of Sweden, for example, the 'shift' recorded in the early 1990s resulted in an extension of the growing season by at least one month (Weyhenmeyer, 2001). Different phytoplankton groups responded differently to this sudden warming. Although there was no increase in the total biomass recorded between May and October, the biomass of temperature-sensitive groups, such as the cyanobacteria and chlorophytes, increased in spring and early summer. Very similar patterns have been observed in a series of 17 lakes studied in Switzerland, Germany, Sweden and the UK. When the composition of the phytoplankton was compared in two contrasting years (1987 and 1989), much higher biomasses were recorded during the warm winter of 1989 (Weyhenmeyer et al., 2002). Cyanobacteria were most affected, and their annual mean biomass increased by a factor of as much as 100 when the two extreme years were compared. Several recent studies (Paerl and Huisman, 2008, 2009; Jöhnk et al., 2008) have shown that climate change is a potential catalyst for the further expansion of harmful cyanobacteria in eutrophic lakes. Rising temperatures, reduced cloud cover in combination with high nutrient loading all favor cyanobacterial dominance. Blooms increase the turbidity of lakes, can deplete oxygen levels, and often produce a bad smell. Moreover, many species of cyanobacteria can produce toxins that can cause serious liver, digestive, neurological, and skin diseases in animals as well as humans. More studies are needed on the factors influencing the development of toxic versus non-toxic strains of cyanobacteria. It has recently been shown that competition between toxic and non-toxic strains of Microcystis is strongly influenced by the light regime experienced in the critical spring-summer period (Kardinaal et al., 2007).

The effects associated with the inter-annual variation in the summer weather were most pronounced in the more productive lakes of the English Lake District. Here, short-term changes in the stability of the water column had a major effect on the seasonal development of bloom-forming species of cyanobacteria, such as Anabaena, 
Aphanizomenon, and Microcystis. In the last forty years, there has been a significant increase in the number of calm, anticyclonic days recorded in this region during the summer (Briffa et al., 1990). George (2006) has shown that these changes have had a direct effect on the physical stability of the lakes and an indirect effect on the seasonal development of the plankton (George and Taylor, 1995). Such 'extreme - events' have also had some effect on the seasonal development of the phytoplankton in larger, less productive lakes. For example, in 2002, the warmest summer ever recorded in northern Europe, the increased thermal stability of Lake Mälaren in Sweden resulted in a.greatly increased consumption of oxygen in deep water, much higher concentrations of nutrients in the hypolimnion and nutrient depletion in the surface water. In autumn, the sudden transfer of nutrients from deep water, combined with the high water temperatures, resulted in an unusually intense bloom of cyanobacteria. The severity of these blooms may also have been influenced by the rainy periods experienced the preceding year. These periods led to a distinct increase in the chemical loading of Lake Mälaren and an associated increase in the colour of the water (Weyhenmeyer et al., 2004). Significant increases in lake water colour and DOC concentrations have recently been reported from a number of European lakes (see Chapter 12 this volume). Such changes are known to have a positive feedback effect on lake surface temperatures and can lead to the development of steeper and longer lasting periods of thermal stratification as more heat is absorbed near the surface. High concentrations of phytoplankton also act as an optically active substance in the water, absorbing and scattering the downwelling irradiance and storing more heat in the upper part of the water column (Arst, 2003; Paerl and Huisman, 2008). The surface temperature within cyanobacterial blooms in Lake IJsselmeer, Netherlands, was $3^{\circ} \mathrm{C}$ above ambient waters (Ibelings et al., 2003). This could represent an important positive feedback mechanism, whereby buoyant cyanobacteria locally enhance surface temperatures, which in turn favors their competitive dominance over eukaryotic phytoplankton (Hense, 2007). Summer heat-budget calculations for two large enclosures installed in Blelham Tarn (English Lake District) demonstrated convincingly that more heat was absorbed near the surface and more lost by nighttime cooling in the enclosure when the concentration of phytoplankton was very high (Jones et al., 2005). In this enclosure, the increased absorption of solar radiation at the surface and the decreased penetration of light both raised the thermocline and strengthened the temperature gradient. The authors suggested that these changes would have quite a complex effect on the algae by increasing their growth rates in the mixed layer whilst reducing the overall depth of the euphotic zone. The importance of water clarity relative to wind mixing in determining the mixing depth or the depth of thermocline or mixing decreases with increasing lake size and has little effect on lakes with a surface area greater than $5 \mathrm{~km}^{2}$ (Fee et al., 1996). As the world becomes warmer, the consequent intensification of stratification is likely to increase the depletion of oxygen in deep water, inhibit the transfer of nutrients from the hypolimnion and limit the vertical movement of passively floating algae.

Analyses of the kind reported here, where changes in the composition and seasonal dynamics of lake phytoplankton are related to long-term changes in the climate have inherent strengths and weaknesses. In some cases, the processes 
responsible for this linkage are quite clear but in others this is still a matter for some speculation. These observations are, however, very useful for validating the results of simulation models (Chapter 15 this volume) and quantifying the impact of extreme climatic events. In many CLIME lakes, the observed changes in the phytoplankton could be related unequivocally to changes in the physical characteristics of the lakes. The main weakness of the observational approach is that there are several interfering processes such as eutrophication, reoligotrophication, changes in acid deposition and so on, that go on in parallel with the climatic variations and influence the growth of the phytoplankton in similar ways. The sensitivity of phytoplankton communities to climatic signals is further complicated by issues such as geographic location, lake type and the trophic status of the individual lakes. In this respect, the spatial coherence analyses described in Chapter 17 can prove most illuminating especially if combined with the functional group approach advocated by e.g. Reynolds et al. (2002). The studies carried out on a homogenous set of perialpine lakes (Anneville et al,, 2004, 2005) represent a good example of this approach but the data sets acquired from other regions are still underexploited.

Acknowledgenients The CLIME project was supported under contract EVK1-CT-2002-00121 by the Energy, Environment and Sustainable Development (EESD) Programme of the 5th EU Framework Programme for Research and Technological Development.

\section{References}

Adrian, R., Deneke, R., Mischke, U., Stellmacher, R. and Lederer, P. (1995) A long term study of the Heiligensee (1975-1992), Evidence for effects of climatic change on the dynamics of eutrophied lake ecosystems, Archiv für Hydrobiologie 133, 315-337.

Adrian, R., Walz, N., Hintze, T., Hoeg, S. and Rusche, R. (1999) Effects of ice duration on plankton succession during spring in a shallow polymictic lake, Freshwater Biology 41, 621-632.

Adrian, R., Wilhelm, S. and Gerten, D. (2006) Life-history traits of lake plankton species may govern their phenological response to climate warming, Global Change Biology 12, 652-661.

Anneville, O., Ginot, V. and Angeli, N. (2002a) Restoration of Lake Geneva: Expected versus observed responses of phytoplankton to decreases in phosphorus, Lakes and Reservoirs: Research and Management 7, 67-80.

Anneville, O., Souissi, S., Ibanez, F., Ginot, V., Druart, J.C. and Angeli, N. (2002b) Temporal mapping of phytoplankton assemblages in Lake Geneva: Annual and interannual changes in their patterns of succession, Limnology and Oceanography 47, 1355-1366.

Anneville, O., Souissi, S., Gammeter, S. and Straile, D. (2004) Seasonal and inter-annual scales of variability in phytoplankton associations: Comparison of phytoplankton dynamic among 3 pre-alpine lakes over a period of 28 years, Freshwater Biology 49, 98-1 15.

Anneville, O., Gammeter, S. and Straile, D. (2005) Phosphorus decrease and climate variability: Mediators of synchrony in phytoplankton changes among European peri-alpine lakes, Freshwater Biology 50, 1731-1746.

Arst, H. (2003) Optical properties and remote sensing of multicomponental water bodies, Springer, Berlin, Heidelberg, New York.

- Arvola, L. and Kankaala, P. (1989) Winter and spring variability in phyto- and bacterioplankton in lakes with different water colour, Aqua Fennica 19, 29-39.

Blenckner, T. (2001) Climate related impacts on a lake: From physics to biology, Comprehensive Summaries of Uppsala Dissertations from the Faculty of Science and Technology 674, Tryck and Medier., Uppsala. 
Blenckner, T. (2005) A conceptual model of climate-related effects on lake ecosystems, Hydrobiologia 533, 1-14.

Bossard, P., Gammeter, S. and Lehmann, C. (2001) Limnological description of Lake Zürich, Ulcerne, and Cadagno, Aquatic Sciences 63, 225-249.

Briand, J.-F., Leboulanger, C., Humbert, J.-F., Bernard, C. and Dufour, P. (2004) Cylindrospermopsis raciborskii (Cyanobacteria) invasion at mid-latitudes: Selection, wide physiological tolerance, or global warming? Journal of Phycology 40, 231-238.

Briffa, K.R., Jones, P.D. and Kelly, P.M. (1990) Principal component analysis of the Lamb Classification of daily weather types. Part 2, seasonal frequencies and update to 1987 , International Journal of Climatology 10, 549-563.

Bright; D.I. and Walsby, A.E. (2000) The daily integral of growth by Planktothitx rubescens calculated from growth rate in culture and irradiance in Lake Zürich, New Phytologist 146, 301-316.

Bürgi, H. and Stadelmann, P. (2002) Change of phytoplankton composition and biodiversity in Lake Sempach before and during restoration, Hydrobiologia 469, 33-48.

Couté, A., Leitao, M. and Martin, C. (1997) Première observation du genre Cylindrospermopsis (Cyanophyceae, Nostocales) en France, Cryplogamie Algol 18, 57-70.

Davis, P.A., Dent, M., Parker, J., Reynolds, C.S. and Walsby, A.E. (2003) The annual cycle of growth rate and biomass change in Planktothrix spp. in Blelham Tarn, English Lake District, Freshwater Biology 48, 852-867.

Dokulil, M.T. and Mayer, J. (1996) Population dynamics and photosynthetic rates of a Cylindrospermopsis - Limnothrix association in a highly eutrophic urban lake, Alte Donau, Vienna, Austria, Algological Studies 83, 179-195.

Dokulil, M.T. and Teubner, K. (2000) Cyanobacterial dominance in lakes, Hydrobiologia 438, $1-12$.

Fee, E.J., Hecky, R.E., Kasian, S.E.M. and Cruikshank, D.R. (1996) Effects of lake size, water clarity, and climatic variability on mixing depths, in Canadian Shield lakes, Limnology and Oceanography 41, 912-920.

Foy, R.H., Gibson, C.E. and Smith, R.V. (1976) The influence of daylength, light intensity and temperature on the growth rates of planktonic blue-green algae, European Journal of Phycology 11., 151-163.

George, D.G. (2000a) Remote sensing evidence for the episodic transport of phosphorus from the littoral zone of a thermally stratified lake, Freshwater Biology 43, 571-578.

George, D.G. (2000b) The impact of regional-scale changes in the weather on the long-term dynamics of Eudiaptomius and Daphnia in Esthwaite Water, Cumbria, Freshwater Biology 43, $111-121$.

George, D.G. (2006) Lakes as integrators and amplifiers of the local climate, Verhandlungen der Internationalen Vereinigung fiir Theoretische und Angewandte Limnologie 29, 1966-1970.

George, D.G. (2007). The Impact of the North Atlantic Oscillation on the development of ice on Lake Windermere, Climate Change 81, 455-468.

George, D.G. and Taylor, A.H. (1995). UK lake plankton and the Gulf Stream, Nature 378, 139, London.

George, D.G. and Hurley, M.A. (2004) The influence of sampling frequency on the detection of long-term change in three lakes in the English Lake District, Aquatic Ecosystem Health Manaement $7,1-14$.

George, D.G., Hewitt, D.P., Lund, J.W.G. and Smyly, J.P. (1990). The relative effects of enrichment and climatic change on the long-term dynamics of Daphnia in Esthwaite Water, Cumbria, Freshwater Biology 23, 55-70.

George, D.G., Maberly, S.C. and Hewitt, D.P. (2004) The influence of the North Atlantic Oscillation on the physical, chemical and biological characteristics of four lakes in the English Lake District, Freshwater Biology 49, 760-774.

George, D.G., Hurley, M.A. and Hewitt, D.P. (2007) The impact of climate change on the physical characteristics of the larger lakes in the English Lake District, Freshwater Biology 52, 1647-1666. 
Gerten, D. and Adrian, R. (2000) Climate driven changes in spring plankton dynamics and the sensitivity of shallow polymictic lakes to the North Atlantic Oscillation, Limnology and Oceanography 45, 1058-1066.

Gibson, C.E. (1987) Adaptations in Oscillatoria redekei at very slow growth rates - changes in growth efficiency and phycobilin complement, European Journal of Phycology 22, $187-191$.

Gorzó, G. (1987) Fizikai és kémiai faktorok hatása a Balatonban elöforduló heterocisztás cianobaktériumok spóráinak csírázására [The influence of physical and chemical factors on the germination of spores of heterocystic cyanobacteria in Lake Balaton], Hidrológiai Közlöny 67, 127-133 [in Hungarian with English summary].

Granin, N.G., Jewson, D., Gnatovsky, R.Y., Levin, L.A., Zhdanov, A.A., Averin, A.I., Gorbunova, L.A., Tsekhanovskii, V.V., Doroschenko, L.F., Min'ko, N.P. and Grachev, M.A. (I999) Turbulent mixing in the water layer just below the ice and its role in development of diatomic algae in Lake Baikal, Doklady Akademii Nauk 366, 835-839 [in Russian].

Greisberger, S. and Teubner, K. (2007) Does pigment composition reflect phytoplankton community structure in differing temperature and light conditions in a deep alpine lake? An approach using HPLC and delayed fluorescence (DF) techniques, Journal of. Phycology 43, 1108-1119.

Huisman, J. and Weissing, F.J. (1994) Light-limited growth and competition for light in well-mixed aquatic environments: An elementary model, Ecology 75, 507-520.

Humbert, J.-F. and Le Berre, B. (2001) Genetic diversity in two species of freshwater cyanobacteria, Planktothrix (Oscillatoria) rubescens and $P$. agardhii, Archiv für Hydrobiologie 150, 197-206.

Jacquet, S., Briand, J.-F., Leboulanger, C., Avois-Jacquet, C., Oberhaus, L., Tassin, B., VinçonLeite, B., Paolini, G., Druart, J.-C., Anneville, O. and Humbert, J.-F. (2005) The proliferation of the toxic cyanobacterium Planktothrix rubescens following restoration of the largest natural French lake (Lac du Bourget), Harmful Algae 4, 651-672.

Järvinen, M., Lehtinen, S. and Arvola, L. (2006) Variations in phytoplankton assemblage in relation to environmental and climatic variation in a boreal lake, Verhandlungen der Inteinationalen Vereinigung der Limnologie. 29, 1841-1844.

Jassby, A.D. and Goldman, C.R. (1974) Loss rates from a lake phytoplankton community, Limnology and Oceanography 19,618-627.

Jöhnk, K.D., Huisman, J., Sharples, J., Sommeijer, B., Visser, P.M. and Stroom, J.M. (2008) Summer heatwaves promote blooms of harmful cyanobacteria, Global Change Biology 14, 495-512.

Jones, R.I. (1991) Advantages of diurnal vertical migrations to phytoplankton in sharply stratified, humic forest lakes, Archiv für Hydrobiologie 120, 257-266.

Jones, I., George, G. and Reynolds, C. (2005) Quantifying effects of phytoplankton on the heat budgets of two large limnetic enclosures, Freshwater Biology 50, 1239-1247.

Kangro, K., Laugaste, R., Nõges, P. and Ott, I. (2005) Long-term changes and seasonal development of phytoplankton. in a strongly stratified, hypertrophic lake, Hydrobiologia $\mathbf{5 4 7}$, 91-103.

Kardinaal, W.E.A., Janse, I., Kamst-van-Agterveld, M., Meima, M., Snoek, J., Mur, L.R., Huisman, J., Zwart, G. and Visser, P.M. (2007) Microcystis genotype succession in relation to microcystin concentrations in freshwater lakes, Aquatic Microbial Ecology 48, 1-12.

Kelley, D.E. (1997) Convection in ice-covered lakes, effects on algal suspension, Journal of Plankton Research 19, 1859-1880.

Kozhov, M. (1963) Lake Baikal and its life, Dr. W. Junk Press, The Hague.

Kozhova, O.M. and Izmest'eva, L.R. (1998) Lake Baikal, evolution \& biodiversity, Backhuys, Netherlands.

Krienitz, L. and Hegewald, E. (1996) Über das Vorkommen von wärmeliebenden Blaualgenarten in einem norddeutschen Gewässer, Lauterbornia 26, 55-63.

Livingstone, D.M. (1997) An example of the simultaneous occurrence of climate-driven "Sawtooth" deep-water warming/cooling episodes in several Swiss lakes, Verhandlungen der Internationalen Vereinigung für Theoretische und Angewandte limnologie 26, 822-828. 
Nõges, T. (2004) Reflection of the changes of the North Atlantic Oscillation index and the Gulf Stream Position Index in the hydrology and phytoplankton of Võrtsjärv, a large, shallow lake in Estonia, Boreal Enviromment Research 9, 401-407.

Nõges, T., Nõges, P. and Laugaste, R. (2003) Water level as the mediator between climate change and phytoplankton composition in a large shallow temperate lake, Hydrobiologia 506-509, 257-263.

Nõges, P., Laugaste, R. and Nõges, T. (2004) Phytoplankton, In J. Haberman, E. Pihu and A. Raukas (eds.), Lake Võrlsjärv, Estonian Encyclopedia Publishers, Tallinn, pp. 217-231.

Ohlendorf, C., Bigler, C., Goudsmit, G.-H., Lemcke, G., Livingstone, D.M., Lotter, A.F., Müller, B. and Sturm, M. (2000) Causes and effects of long periods of ice cover on a remote high Alpine lake, Journal of. Limnology 59 (Suppl. 1), 65-80.

Padisák, J. (1997) Cylinidrospermopsis raciborskii (Woloszynska) Seenayya et Subba Raju, an expanding, highly adaptive cyanobacterium, worldwide distribution and review of its ecology, Archiv für Hydrobiologie/Supplement 107 (Monographic Studies), 563-593.

Padisák, J. (1998) Sudden and gradual responses of phytoplankton to global climate change, case studies from two large, shallow lakes (Balaton, Hungary, and the Neusiedlersee, Austria/Hungary), In D.G. George, J.G. Jones, P. Puncochar, C.S. Reynolds and D.W. Sutcliffe (eds.), Management of lakes and reservoirs during global climate change, NATO ASI series, Kluwer Academic Publishers, Dordrecht, 42, 111-125.

Padisák, J., Barbosa, F.A.R., Koschel, R. and Krienitz, L. (2003a) Deep layer cyanoprokaryota maxima are constitutional features of lakes, examples from temperate and tropical regions, Archiv für Hydrobiologie, Special Issues Advances in Limnology 58, 175-199.

Padisák, J., Scheffler, W., Sípos, C., Kasprzak, P., Koschel, R. and Krienitz, L. (2003b) Spatial and temporal pattern of development and decline of the spring diatom populations in Lake Stechlin in 1999, Archiv für Hydrobiologie, Special lssues Advances in Limnology 58, 135-155.

Padisák, J., Molnár, G., Soróczki-Pintér, É., Hajnal, É. and George, D.G. (2006) Four consecutive dry years in Lake Balaton (Hungary), consequences for phytoplankton biomass and composition, Verhandlungen der Internationalen Vereinigung der Limnologie 29, 1153-1 159.

Paerl, H.W. and Huisman, J. (2008) Blooms like it hot, Science 320, 57-58.

Paerl, H.W. and Huisman, J. (2009) Climate change: A catalyst for global expansion of harmful cyanobacterial blooms, Environmental Microbiology Reports 1, 27-37.

Pearson, R.G. and Dawson, T.P. (2003) Predicting the impacts of climate change on the distribution of species, are bioclimate envelope models useful? Global Ecology and Biogeography 12, $361-371$.

Peeters, F., Straile, D., Lorke, A. and Ollinger, D. (2007) Turbulent mixing and phytoplankton spring bloom development in a deep lake, Limnology and Oceanography 52, 286-298.

Pettersson, K., Grust, K., Weyhenmeyer, G. and Blenckner, T. (2003) Seasonality of chlorophyll and nutrients in Lake Erken - effects of weather conditions, Hydrobiologia 506-509, 75-81.

Phillips, K.A. and Fawley, M.W. (2002) Winter phytoplankton blooms under ice associated with elevated oxygen levels, Journal of Phycology 38, 1068-1073.

Psenner, R. (2003) Alpine lakes, Extreme ecosystems under the pressure of global change, EAWAG News 55, 12-14.

Reynolds, C.S. (2006) The ecology of phytoplankton (ecology, biodiversity and conservation), Cambridge University Press, Cambridge, New York.

Reynolds, C.S., Oliver, R.L. and Walsby, A.E. (1987) Cyanobacterial dominance: The role of buoyancy regulation in dynamic lake environments, New Zealand Journal of Marine and Freshwater Research 21, 379-390.

Reynolds, C.S., Padisák, J. and Sommer, U. (1993) Intermediate disturbance in the ecology of phytoplankton and the maintenance of species diversity, a synthesis, Hydrobiologia 249, 183-188.

Reynolds, C.S., Huszar, V., Kruk, C., Naselli-Flores, L. and Melo, S. (2002) Towards a functional classification of the freshwater phytoplankton, Journal of Plankton Research 24, $417-428$. 
Rücker, J., Wiedner, C. and Zippel, P. (1997) Factors controlling the dominance of Planktothrix agardhii and Limnothrix redekei in eutrophic shallow lakes, Hydrobiologia 342-343, $107-115$.

Sas, H. (ed.) (1989) Lake restoration by reduction of mutrient loading: Expectations, experiences, extrapolations, Academia Verlag Richarz GmbH, Sankt Augustin, Germany, 497 pp.

Salmaso, N. (2002) Ecological patterns of phytoplankton assemblages in Lake Garda: Seasonal, spatial and historical features, Journal of Limnology 61, 95-115.

Salmaso, N. (2005) Effects of climatic fluctuations and vertical mixing on the interannual trophic variability of Lake Garda, Italy, Limnology Oceanography 50, 553-565.

Scheffler, W. and Padisák, J. (2000) Siephanocostis chantaicus (Bacillariophyceae), morphology and population dynamics of a rare centric diatom growing in winter under ice in the oligotrophic Lake Stechlin, Germany, Archiv fur Iydrobiology 98/Algological Studies 133, 49-69.

Schmidt, W. (1928) Über Temperatur und Stabilitatsverhaltnisse von Seen, Geographiska Annaler 10, 145-177.

Sorvari, S., Korhola, A. and Thompson, R. (2002) Lake diatom response to recent Arctic warming in Finnish Lapland, Global Change Biology 8, 171-181.

Steel, J.A. and Duncan, A. (1999) Modelling the ecological aspects of. bankside reservoirs and implications for management, Hydrobiologia 395/396, 133-147.

Stefaniak, K. and Kokocynski, M. (2005) Occurrence of invasive Cyanobacteria species in polimictic lakes of the Wielkopolska region (Western Poland), Oceanological and Hydrobiological Research 34 (Suppl 3), 137-148.

Straile, D. (2000) Meteorological forcing of plankton dynamics in a large and deep continental European lake, Oecologia 122, 44-50.

Straile, D. and Adrian, R. (2000) The North Atlantic Oscillation and plankton dynamics in two European lakes - two variations on a general theme, Global Change Biology 6, 663-670.

Straile, D., Joehnk, K. and Rossknecht, H. (2003) Complex effects of winter warming on the physico-chemical characteristics of a deep lake, Limnology and Oceanography 48, 1432-1438.

Stuken, A., Rücker, J., Endrulat, T., Preussel, K., Hemm, M., Nixdorf, B., Karsten, U. and Wiedner, C. (2006) Distribution of three alien cyanobacterial species (Nostocales) in northeast Germany, Cylindrospermopsis raciborskii, Anabaena bergii and Aphanizomenon aphanizomenoides, Phycologia 45, 696-703.

Talling, J.F. (1993) Comparative seasonal changes and inter-annual variability and stability in a 26-year record of total phytoplankton biomass in four English lake basins, Hydrobiologia 268, $65-98$.

Talling, J.F. (2003) Phytoplankton-zooplankton seasonal timing and the 'clear-water phase' in some English lakes, Freshwater Biology 48, 39-52.

Teubner, K., Tolotti, M., Greisberger, S., Morscheid, H., Dokulil, M.T. and Morscheid, H. (2003) Steady state phytoplankton in a deep pre-alpine lake: Species and pigments of epilimnetic versus metalimetic assemblages, Hydrobiologia 502, 49-64.

Teubner, K., Tolotti, M., Greisberger, S., Morscheid, H., Dokulil, M.T. and Kucklentz, V. (2006) Steady state of phytoplankton and implications for climatic changes in a deep pre-alpine lake: Epilimnetic versus metalimnetic assemblages, Verhandlungen der Internationalen Vereinigung fiir Theoretische und Angewandte Limnologie 29, 1688-1692.

Tõnno, 1. and Nõges, T. (2003) Nitrogen fixation in a large shallow lake: Rates and initiation conditions, IIydrobiologia 490, 23-30.

Tóth, L.G. and Padisák, J. (1986) Meteorological factors affecting the bloom of Anabaenopsis raciborskii Wolosz. (Cyanophyta, Hormogonales) in the shallow Lake Balaton, Hungary, Jounal of Plankton Research 8, 353-363.

Tulonen, T., Kankaala, P., Ojala, A. and Arvola, L (1994) Factors controlling production of phytoplankton and bacteria under ice in a humic, boreal lake, Journal of Plankton Research 16, $1411-1432$.

Walsby, A.E. (2005) Stratification by cyanobacteria in lakes: A dynamic buoyancy model indicates size limitations met by Planktothrix rubescens filaments, New Phytologist 168, 365-376. 
Walsby, A., Avery, A. and Schanz, F. (1998) The critical pressures of gas vesicles in Planktothrix rubescens in relation to the depth of winter mixing in Lake Zurich, Switzerland, Journal of Plankton Research 20, 1357-1375.

Walsby, A.E. Schanz, F. and Schmid, M. (2006) The Burgundy-blood phenomenon: A model of buoyancy change explains autumnal waterblooms by Planktothrix mibescens in Lake Zürich, New Phylologist 169, 109-122.

Walther, G.-R., Post, E., Convey, P., Menzel, A., Parmesan, C., Beebee, T.J.C., Fromentin, J.-P., Hoegh-Guldberg, O..and Bairlein, F. (2002) Ecological responses to recent climate change, Nature 416, 389-395.

Watson, S.B., Satchwill, T., Dixon, E. and McCauley, E. (2001) Under-ice blooms and sourcewater odour in a nutrient-poor reservoir: Biological, ecological and applied perspectives, Fresh water Biology 46, 1553-1567.

Weckström, J. and Korhola, A. (2001) Patterns in the distribution, composition and diversity of diatom assemblages in relation to ecoclimatic factors in Arctic Lapland, Journal of Biogeography $28,31-45$.

Weyhenmeyer, G.A. (2001) Warmer winters - are planktonic algal populations in Sweden's largest lakes affected? Ambio 30, 565-571.

Weyhenmeyer, G.A., Blenckner, T. and Pettersson, K. (1999) Changes of the plankton spring outburst related to the North Atlantic Oscillation, Limnology and Oceanography 44, 1788-1792.

Weyhenmeyer, G.A., Adrian, R., Gaedke, U., Livingstone, D.M. and Maberly, S.C. (2002) Response of phytoplankton in European lakes to a change in the North Atlantic Oscillation, Verhandlungen Internationale Vereinigung fïr theoretische und angewandte Limnologie 28, 1436-1439.

Weyhenmeyer, G.A., Willen, E. and Sonesten, L. (2004) Effects of an extreme precipitation event on water chemistry and phytoplankton in the Swedish Lake Mälaren, Boreal Environment Research 9, 409-420.

Zotina, T., Köster, O. and Jüttner, F. (2003) Photoheterotrophy and light-dependent uptake of organic and organic nitrogenous compounds by Planktothrix rubescens under low irradiance, Freshwater Biology 48, 1859-1872. 